\title{
E-fulfilment and distribution in omni-channel retailing: a systematic literature review
}

\begin{abstract}
Purpose - Given the progressive growth of e-commerce sales and the rising interest in omni-channel (OC) retailing amongst academics and practitioners, the aim of this study is to provide an up-to-date literature review on the logistics involved when moving towards OC retailing. Specifically, we have examined the main issues relating to e-fulfilment and distribution, highlighting how the topic has been developed over time, and identifying the most promising research streams for the near future.
\end{abstract}

Design/methodology/approach - A Systematic Literature Review methodology is adopted. The review is based on 58 papers published from 2002 to 2017 in 34 international journals. The papers were analysed and categorised according to their defining characteristics, methodologies adopted and themes addressed.

Findings - This paper provides an overview of the main issues relating to e-fulfilment and distribution experienced by companies shifting towards OC, mapped along three dimensions: distribution network design, inventory and capacity management, delivery planning and execution. Despite the growing interest in OC retailing, many key topics are still under-represented, including the evolution of retail distribution networks, assortment planning over multiple channels, the logistics role played by stores in the delivery process and the interplay between different logistics aspects.

Originality/value - The paper offers insights into the main logistics issues in MC and OC retailing, as well as highlights potential fields for further investigation. From a managerial perspective, this paper is useful for retailers adopting an OC approach to guide their future efforts concerning their business logistics model.

Keywords: Omni-channel, logistics, retailing, e-fulfilment, systematic literature review

Paper type: Literature review 


\section{Introduction}

E-commerce has shown an impressive growth in the past decade in all the main markets. In 2016, worldwide e-commerce sales reached $\$ 1.86$ trillion and are expected to grow further over the next years, reaching $\$ 3.88$ trillion in 2019 , at an annual growth rate of above $10 \%$ (Statista, 2017). As highlighted by De Koster (2003), companies that sell online to end customers are either product manufacturers, traditional retailers, online retailers with or without physical premises (e.g. Amazon in the former case, eBay in the latter). While direct sales to customers are still relatively insignificant for manufacturers, retailers are increasingly offering products both online and in-store (Agatz et al., 2008; AT Kearney, 2015). Many traditional retailers are adding an online channel to their portfolio and many online retailers are opening brick and mortar stores or are working in partnership with traditional retailers as a means to provide a more complete offer. More than $50 \%$ of the leading retailers are now adopting a multiple channel approach, and their numbers are growing (Hübner et al., 2015).

Retailers initially started developing multi-channel (MC) systems to meet the additional challenges thrown up by the success of e-commerce. At the beginning, these MCs worked in isolation, leading to fragmented supply chains while retailers found it extremely difficult to offer a satisfactory consumer experience (Wilding, 2013). Several authors have recently argued that the retailing industry is moving into a new phase where the distinction between traditional and online channels is lost, known as omni-channel (OC) retailing (Beck and Rygl, 2015; Verhoef et al., 2015). In an OC system, customers can move seamlessly from one channel to another. Rather than deciding whether multiple channels should be used (Hübner et al., 2016c), the newest challenge is now to understand how multiple channels can be managed synergistically to provide a satisfactory customer experience. MC and OC management concepts are shown in Table I.

\section{XXXXXXXXXXXXXXXXXXXXXXXXXXXXXXXXXXXXXXXXXXXXXXXXXXXXXXX}

\section{Take in Table I}

\section{XXXXXXXXXXXXXXXXXXXXXXXXXXXXXXXXXXXXXXXXXXXXXXXXXXXXXXX}

In this landscape, retailing models and logistics-related paradigms are changing significantly. OC retailing is first and foremost a major logistics challenge because e-commerce differs from the traditional retail in many aspects, among which are the picking unit (pieces instead of cases) and the delivery process (Metters and Walton, 2007). Retailers need to create new logistics models, evaluating the trade-off between the process of integration and separation between the different channels (Hübner et al., 2015). A total separation strategy meets the specific requirements of each 
channel, whereas an OC strategy can provide economies of scale and reduce total costs (Gallino and Moreno, 2014; Jeanpert and Paché, 2016).

In literature, the interest in studying critical issues relating to e-fulfilment and distribution in retailing has progressively expanded, with a rapid increase in the contributions of academic experts covering this aspect (Mahar et al., 2014; Li et al., 2015a; Jeanpert and Paché, 2016). Moreover, OC retailing seems to be a promising research stream for future research (Hübner et al., 2016a; Ishfaq et al., 2016). Only a few literature reviews are already available that specifically analyse the e-fulfilment and distribution issues faced by companies selling products both online and through traditional channels. We found three reviews concerned with e-commerce and its impact on the retail process, drawn up respectively by: Lee and Whang (2001), who identified five e-fulfilment strategies for winning the last-mile; Swaminathan and Tayur (2003), who reviewed models for supply chains in e-businesses; and Burt and Sparks (2003), who analysed the impact of e-commerce on retail processes discussing, among other aspects, key topics such as sourcing, inventory, picking and distribution of goods. These reviews are, however, relatively old, given the nature of the subject, and they discuss neither MC systems, nor the interplay across channels in an OC perspective. More recently, the focus of practitioners and academics has shifted to the co-existence of multiple sales channels. In a review by Agatz et al. (2008), the authors analyse distribution network design, warehouse design and inventory and capacity management from a supply chain viewpoint. However, their review concentrates exclusively on modelling-based papers, and the models included in their study mainly take a singlechannel perspective, e.g. focusing on e-fulfilment. We also identified a review by Zhang et al. (2010), where the authors analyse the interplay of e-commerce and traditional retailing, although here they adopted a marketing perspective. Over recent years, a few attempts were made to review contributions concerning $\mathrm{OC}$ retailing, highlighting the differences between $\mathrm{MC}$ and $\mathrm{OC}$ concepts and presenting the current topics discussed in OC management research (Mirsch et al., 2016; Wollenburg, 2016). These are, however, essentially working papers, often incomplete (e.g. with the focus on a particular methodology) and/or not specifically concerned with logistics issues. There is, therefore, a lack of up-to-date, structured reviews that offer a comprehensive overview of the main issues relating to efulfilment and distribution encountered by companies moving towards OC retailing.

Coherently with the above-reported analysis, the main objective of the present paper is to fill this gap by offering a systematic review of the recent contributions on e-fulfilment and distribution in view of moving towards OC retailing, highlighting how the topic has been developed over time, and identifying the most promising research streams for the near future.

The paper is organised as follows. The next section describes the methodology adopted. The third section reports and discusses the review results. The fourth section presents the identified gaps and 
proposes the directions for future research in this field. In the final section, the conclusions are drawn and research limitations are identified.

\section{Methodology}

A Systematic Literature Review (SLR) was selected as the research method for this study because it is particularly suited to our objectives, where the aim is to understand trends and detect existing gaps in the scientific literature (Lagorio et al., 2016). SLRs usually entails 'integrating a number of different works on the same topic, summarising the common elements, contrasting the differences, and extending the work in some fashion' (Meredith, 1993, p. 8). It is, therefore, a valuable methodology for developing propositions and discussing future research implications (Carter and Rogers, 2008). As highlighted by Lagorio et al. (2016), the SLR method has been already widely used to consolidate emerging topics in other areas, such as the role of logistics in achieving supply chain agility (Gligor and Holcomb, 2012), extending sustainability codes to suppliers (Gimenez and Tachizawa, 2012), and the servitisation of manufacturing (Lightfoot et al., 2013).

In order to reduce bias during research and ensure replicability, this study followed the guidelines set out by Denyer and Tranfield (2009). A five-step methodology was adopted, as illustrated in Figure 1. These phases are described in detail in the following sub-sections.

\section{XXXXXXXXXXXXXXXXXXXXXXXXXXXXXXXXXXXXXXXXXXXXXXXXXXXXXXX}

Take in Figure 1

\section{XXXXXXXXXXXXXXXXXXXXXXXXXXXXXXXXXXXXXXXXXXXXXXXXXXXXXXX}

\section{Question formulation}

The first step in an in-depth literature review is to develop a clear focus (Light and Pillemer, 1984). Therefore, we have rigorously addressed clearly-defined research questions, which have to be well specified, informative and clearly formulated to avoid ambiguity (Hohenstein et al., 2015). In our paper, we formulated the following research questions:

RQ1: What are the main issues related to e-fulfilment and distribution in retailing, and how have they developed over time?

RQ2: What is the research agenda for e-fulfilment and distribution when moving towards OC retailing? 


\section{Locating papers}

The purpose of searching through relevant journal papers is to create a comprehensive list of core contributions pertinent to the review questions (Denyer and Tranfield, 2009). To reduce any research bias, the study involves many researchers from different countries, it investigates three databases and avoids limiting itself to any timeframe, specific journals or publishing outlets (Tranfield et al., 2003). In particular, we selected Science Direct, Scopus and the Web of Science, as they have some of the largest business research repositories and are typically used in literature reviews.

Consistently with other SLRs in management (Lagorio et al., 2016; Hohenstein et al., 2015), in our review, defined keywords were used as the search criteria. Since the aim of the present research is to identify the main issues relating to e-fulfilment and distribution in the shift towards OC retailing, we used a combination of terms pertaining to both areas (e.g. 'omni-channel retail' and 'logistics', with all the related terms), searching for them in the title, keywords and abstract. As an example, a full list of keywords and the code from Scopus search can be found in Table II.

As suggested by Marchet et al. (2014) and commented on by Hohenstein et al. (2015), we also went back to other papers through cross-referencing in order to include potential papers that had not been selected from the above-mentioned databases. Furthermore, as suggested by Denyer and Tranfield (2009), we also included papers on the basis of recommendations made by experts. By applying this method, we are confident of having included all the main contributions in this field.

\section{XXXXXXXXXXXXXXXXXXXXXXXXXXXXXXXXXXXXXXXXXXXXXXXXXXXXXXX}

Take in Table II

\section{XXXXXXXXXXXXXXXXXXXXXXXXXXXXXXXXXXXXXXXXXXXXXXXXXXXXXXX}

\section{Paper selection and evaluation}

The review was limited to papers published in international peer-reviewed journals, following Touboulic and Walker (2015), to ensure a certain level of quality.

We scanned first the databases for the specified keywords with no time limit, thus from the first papers appearing in 1997 to January 2017. Our analysis resulted in a preliminary sample of 351 contributions.

Next, through the careful analysis of abstracts, introductions and conclusions, we were able to distinguish between relevant and irrelevant papers. To ensure the rigour of this SLR process, reducing any subjective bias and enhancing validity, each paper was read independently by two authors. Studies that we felt were non-relevant to our formulated research questions were eliminated. In 
particular, we excluded papers with a merely marketing perspective and papers where ' $\mathrm{MC} / \mathrm{OC}$ retailing' and/or 'logistics' were only a secondary concern. As the outcome of this process, 76 papers were selected.

Finally, all selected contributions were read in their entirety, again by two authors independently. By cross-referencing all the citations and bibliographies and talking with experts in the field, we identified a number of potential contributions that might otherwise have been missed, resulting in a database containing 58 academic peer-reviewed journal papers. These contributions were included in the literature review to ensure the high quality and comprehensiveness of this study.

\section{Analysis and synthesis}

All papers selected for this study were randomly entered onto a Microsoft Excel spreadsheet (Durach et al., 2015), and were then analysed in depth and individually classified according to the following criteria:

- Defining characteristics. The selected contributions were classified according to their general details - year of publication, journal title, authors' country/nationality.

- Methodology adopted. In line with Seuring and Müller (2008) and Winter and Knemeyer (2013), five research methodologies were distinguished: theoretical and conceptual papers, case studies/interviews, surveys, modelling papers, literature reviews. In the case of multiple methodologies, each paper was classified according to the primary methodology used.

- Themes addressed. Finally, the collected papers were classified according to the focus of each study and the key issues investigated.

In terms of thematic scope, by recursively considering the topics found in the literature and the evidence that had emerged from our discussions with experts, we identified three key themes, each comprising several issues involved in setting up e-fulfilment and distribution in view of OC retailing:

(1) distribution network design, in terms of the distribution system and the design of logistics facilities;

(2) inventory and capacity management, in terms of assortment planning for the different channels and replenishment policies;

(3) delivery planning and execution, in terms of delivery services and shipment policies.

It is worth noting that this structure was only set up as a means for organising our discussion. Distribution network design, inventory and capacity management and delivery planning and execution are closely related to each other (Hübner et al., 2015).

Table III summarises the content and features of each paper. Aligned with Mangiaracina et al. (2015), the papers are listed in chronological order to show how e-fulfilment and distribution issues evolve 
over time, as well as to highlight the main differences in addressing those issues when shifting towards OC retailing.

Reporting and using the results

After examining all the selected papers, the emerging evidence was elaborated in order to answer our research questions. In the next section, we will present a summary of our chosen studies in terms of their defining characteristics and methodology adopted and we will discuss the main issues that emerged from the review. We will then highlight the promising research streams for e-fulfilment and distribution when moving towards OC retailing, as per RQ2.

XXXXXXXXXXXXXXXXXXXXXXXXXXXXXXXXXXXXXXXXXXXXXXXXXXXXXXX

Take in Table III

XXXXXXXXXXXXXXXXXXXXXXXXXXXXXXXXXXXXXXXXXXXXXXXXXXXXXXX

\section{Main issues related to e-fulfilment and distribution in retailing \\ General overview of analysed papers}

The 58 papers examined were published between 2002 and 2017 in 34 different journals, including journals specific to the management, marketing, operations and supply chain management areas. The plurality of our chosen papers were published in European Journal of Operational Research (11), International Journal of Retail and Distribution Management (6) and International Journal of Physical Distribution and Logistics Management (4). This result suggests the point that opportunities and challenges relating to a defined OC strategy imply that marketing and logistics issues also come into play, and they are closely interrelated.

Looking at the regions addressed, we can see that, for 21 papers, the first author is USA-based. In a number of other publications, the first author is based in the UK (7), Germany (6) or China (5). These results appear to be roughly in line with the spread of B2C e-commerce in the USA, UK and Germany (i.e. the main markets), as well as reflecting the increase in online shopping in China (i.e. the most promising emerging market).

Looking at the methodology (Figure 2), the analysis shows that papers focusing specifically on logistics topics are in general based on simulation or analytical models (32), while conceptual contributions (6) and empirical studies (based on surveys (8) or case studies and interviews (11)) are less common. Also, as previously noted, we also found a literature review that analyses quantitative models in e-fulfilment and MC distribution (Agatz et al., 2008). 
XXXXXXXXXXXXXXXXXXXXXXXXXXXXXXXXXXXXXXXXXXXXXXXXXXXXXXX

Take in Figure 2

\section{XXXXXXXXXXXXXXXXXXXXXXXXXXXXXXXXXXXXXXXXXXXXXXXXXXXXXXX}

\section{Distribution network design}

Retailers adding the online channel to their existing channel mix need to re-design their distribution network, since the key design variable is the level of integration between online and traditional flows. Retailers can introduce new distribution systems specifically for the online channel, such as dropshipping (Hovelaque et al., 2007) or new distribution centres designed on purpose for the online channel (De Koster, 2003). This means that different channels are not treated as part of the same overall system, but as separate silos. A key element in designing an e-fulfilment centre is the level of automation. The retailer can opt for manual procedures or else introduce semi or fully automated systems (Hübner et al., 2016b). For instance, Hu and Chang (2009) proposed an innovative model, the automated multi-floor distribution centre, which can solve the problems of long-distance delivery and can be conveniently accessed by online customers. According Hübner et al. (2015), the main reasons for separate networks lie in the lack of preconditions for integration (know-how, resources, infrastructure, requirements for picking). At the same time, De Koster (2003) empirically demonstrated that when the number of online orders becomes significant, the most efficient solution is probably to have a warehouse specifically designed for the online channel. In a similar vein, Bendoly et al. (2007) showed that it is possible to identify a threshold, as a percentage of total online demand, above which the best solution would be a dedicated warehouse.

Alternatively, with a view to integration and synergy among several channels - a cornerstone of the emerging OC management approach - retailers can use their existing infrastructure (central warehouse, stores) to fulfil both traditional and online orders. Several contributions found in literature made a comparison between warehouse-based and store-based distribution systems as alternative methods for serving the online demand. In this stream, Alptekinoğlu and Tang (2005) highlighted the importance of considering the correlation between in-store and online demand as part of this decision. Liu et al. (2010) showed that variability in in-store demand served by a warehouse and transport costs are both important parameters when considering a warehouse as a candidate for supplying online demand. Focusing on the integration between online and traditional channels, Bretthauer et al. (2010) proposed a model to determine how many facilities are needed to handle both online and traditional sales in order to minimise logistics costs. Involving existing infrastructures in the e-fulfilment and distribution process also means re-defining their role in the distribution network, and restructuring 
them properly to develop an OC system. In this development, technology is one of the primary drivers (Mirsch et al., 2016). For instance, in re-designing a store, Jeanpert and Paché (2016) underlined the need to provide sales personnel with tablets, introducing an 'everything, all the time, everywhere' approach that allows staff to offer products in other stores or through the online channel and have them delivered either to the customer's home or to the store. As an additional factor, if online and traditional flows are integrated, the traditional processes must also be reviewed. For example, decisions to be taken at warehouse level include whether to introduce common or separated picking areas for different channels, simultaneous or dedicated picking time slots for each channel, and shared or dedicated personnel (Hübner et al., 2016c). In this vein, Ishfaq et al. (2016) suggested that the choice of e-fulfilment policy is connected to the configuration and capabilities of a retailer's existing distribution network. Retailers whose store-replenishment process is structured similarly to what is required for e-fulfilment (i.e. forward placement of inventory and store-replenishment schedule that frequently moves smaller quantities of items from a central warehouse to stores) will find it relatively easy to integrate online orders into their existing warehousing operations by developing a last-mile delivery capability (Ishfaq et al., 2016).

The retailer's allocation policy is another key element to be taken into consideration when a number of different logistics facilities are involved in the e-fulfilment and distribution process. This is the case in an OC system, in which the distinction between traditional and online channels disappears. After having defined how online sales are to be allocated in multiple-channel supply chains (e.g. warehouse-based versus store-based), another important aspect is to decide how often these fulfilment decisions are to be taken. In most existing literature, the assumption is that the location selected for handling the online sales is defined a priori (e.g. the store closest to the customer) and cannot be modified (Chiang and Monahan, 2005; Bretthauer et al., 2010). Technological development has facilitated real-time access to information along the supply chain, making it now possible to use decision models during the execution phase (Swaminathan and Tayur, 2003). Several authors have recently introduced the principle of postponement in this field, proposing dynamic or quasi-dynamic allocation policies for assigning online orders (Mahar and Write, 2009; Mahar et al., 2009b). On the logistics side, this means postponing decisions about changes to the inventory location downstream in the supply chain to the latest possible point (Pagh and Cooper, 1998). 'Whereas static allocation policies pre-specify which location is responsible for handling online sales from each region, dynamic allocation policies determine online fulfilment responsibilities in real time for each incoming online order' (Mahar and Wright, 2009). On this point, Mahar and Wright (2009) demonstrated that delaying decisions about allocation and allowing sales to be accumulated can significantly reduce inventory costs. Mahar et al. (2009b) extended this study, examining how real-time information about inventory 
positions and online demand can be exploited to gain an economic advantage in multiple-channel supply chains by dynamically specifying which logistics facilities will handle each online sale.

Finally, another key issue for companies that are adding the online channel to their existing channel mix is how to manage the return process. In grocery retail, where goods are perishable and less than 1 per cent of online orders are returned, the typical strategy consists in offering a money-back guarantee (Hübner et al., 2016b). Chen and Chen (2017) have shown that the retailer should offer a money-back guarantee in a channel as long as the net salvage value of the returned product is positive for that channel and other strategies should otherwise be considered. The returns management process is a significant issue in non-food retail, where the online channel typically has a high return rate (Bernon et al., 2016). Retailers can introduce new logistics facilities to collect and manage their online returns. Regarding this point, Min et al. (2006) developed a model to determine the optimal number and location of centralised return centres where returned products are to be collected, sorted, combined into large shipments and sent to repair facilities. The literature has highlighted two new management aspects related to OC returns, returns modes (courier delivery, in-store returns) and integration across different returns channels (Bernon et al., 2016). In this vein, many authors have begun to look at using brick and mortar stores as the collection point for all returned products, including those purchased online. For instance, Widodo et al. (2011) proposed a model in which returned products can be managed through a dedicated facility as well as through conventional stores.

\section{Inventory and capacity management}

A key issue for retailers willing to include the online sales into their businesses is the assortment planning over multiple channels. The online channel alters the underlying economics of assortment planning by decoupling inventories from customer display (Randall et al., 2006). While the size of a traditional store determines a limit in the assortment that can be offered, in an online store a retailer can offer virtually limitless assortment (Noble et al., 2005). In the case of an OC approach, with crosschannel objectives (i.e. total sales over channels, overall retail customer experience), retailers often carry key items that are popular sellers in both online channel and stores, and use the online channel as a means of selling highly specialised products that cannot be profitably offered in traditional stores (Berman and Thelen, 2004; Zhang et al., 2010). Recently, some authors analysed assortment decisions faced by manufacturers selling products both online and through traditional channels, looking at the inventory costs (Rodríguez and Aydın, 2015; Matsui, 2016). From the retailing perspective, Bhatnagar and Syam (2014) demonstrated that products with high carrying costs can be profitably withdrawn from stores and be available exclusively online. Li et al. (2015b) argued that, if a product can be delivered rapidly at a relatively low cost, the online channel is to be preferred, 
whereas if the delivery cost is high and consumers are impatient, the traditional channel is better. Furthermore, Hübner et al. (2016c) empirically showed that retailers with several channels start their operations with a smaller online than offline assortment, and then gradually expand their online assortment until it is more substantial than their offline assortment, thus creating a virtual shelf extension.

Additionally, retailers moving towards OC need to evaluate the effect of inventory pooling and decide between a shared or dedicated inventory for the various channels. In this regard, Bendoly (2004) analysed different priority levels concerning the fulfilment of in-store and online demand, and demonstrated that inventory pooling benefits are influenced by the share of the market managed through online sales and by service level constraints. In a related study, Bendoly et al. (2007) demonstrated that the benefits of inventory pooling are a function of the inventory's location within the supply chain, the proportion of a company's demand that is online, and the demand volume per retail store. Hovelaque et al. (2007) confirmed that the impact of inventory pooling in terms of higher service levels and lower operational costs is related to the location of the inventory in the supply chain. In an OC system, where customers can move seamlessly from one channel to another, being able to view the inventory becomes a basic requirement. As a matter of fact, inventory sharing can bring significant benefits in terms of cost reduction, but it can also generate conflicts between the different channels. For instance, Fernie and Grant (2008) empirically illustrated that using the stock available in a store to serve both online and traditional demand can result in acute difficulties regarding on-shelf availability. Having a robust information technology system is a pre-requisite for integrated inventory management, to avoid any availability problems (Fernie and Grant, 2008).

Finally, another key factor is to have an effective inventory replenishment policy in terms of both timing and quantities. Many authors have recently focused their attention on these issues within multiple-channel supply chains. For instance, Geng and Mallik (2007) developed a theoretic game model to analyse the situation where some customers, unhappy at finding one channel out of stock, will visit the other. Schneider and Klabjan (2013) proposed a lost sales model and investigated the conditions for optimal inventory replenishment policies when there are two different sales channels. Kull et al. (2013) investigated the effects of daily inventory record inaccuracy for a retailer fulfilling traditional and online demand from the same distribution centre. Li et al. (2015a) analysed a periodicreview inventory system where the two-fold channel demand is based on the inventory levels for both channels. They argued about the importance of capturing how demand depends on inventory levels when setting an appropriate inventory replenishment policy.

Moreover, in the online channel, where returns are significantly higher than in the traditional channel, it may be advisable to consider product return flows when setting an inventory replenishment policy. 
Even if retailers use marketing policies (e.g. using pricing and product availability information to alert customers about products) to reduce their return flows, in some cases returns are inevitable and should be managed within the retailer's inventory replenishment policy. Most papers available in literature address this issue with a focus on the online channel (Mostard and Teunter, 2006; Mollenkopf et al., 2011). In recent contributions, the analysis has been extended to take in multiplechannel supply chains, including the paper by Li et al. (2013). They proposed a model in which the returned goods go through a simple re-packaging process and re-enter the sales channels.

\section{Delivery planning and execution}

One of the main challenges in online retailing is what is known as the last-mile delivery. The original online sales model implies that customers place orders online and then receive their goods at home. Important design choices regarding home delivery are the speed of delivery and the delivery area (Agatz et al., 2008). Retailers can offer their online customers a more or less rapid delivery (same day, next day, two or more days) and cover a more or less wide area (local, regional, national, international) (Hübner et al., 2016b). Referring to this point, De Koster (2003) have empirically shown that, if delivery times are short, then the company is more likely to distribute locally or regionally rather than internationally. These service elements can also impact on the business logistics model adopted by the company (Hübner et al., 2015). In addition, home delivery can be either attended or unattended (Kämäräinen and Punakivi, 2002). With attended home delivery, the customer must be at home to receive the order, which introduces additional complexity to the operational management process. As a consequence, there is a stream of research focusing on planning and executing an attended home delivery. Agatz et al. (2011) analysed the time slot management problem, whereas Boyer et al. (2009) evaluated the impact of the length of a delivery window on performance, examining the trade-off between cost and service level. These contributions adopt a single channel point of view and they focus mainly on grocery retail, as the main features of this industry are perishable products and the serious implication of logistics costs for overall costs.

In an OC system, retailers are looking for new delivery mechanisms that can provide a high service level in a cost-efficient way. As an alternative to home delivery, many retailers offer their online customers the choice of collecting goods bought online at specific locations, called pick-up points, in a form often referred to as Click\&Collect (Weltevreden, 2008; Lang and Bressolles, 2013). Hübner et al. (2016c) showed that the higher the outlet density, the more beneficial it is for retailers to introduce the Click\&Collect option. Weltevreden (2008) identified two types of pick-up points: locker points (i.e. automatic lockers, in easy-to-access locations within high-density shipment areas, so that goods can be delivered and collected 24/7 all year round) and service points (i.e. using existing 
outlets, such as small convenience stores, petrol stations and railway stations). Focusing on grocery retail, Colla and Lapoule (2012) and Saskia et al. (2016) analysed the possibility of a drive-through delivery mode (Click\&Drive). This is an additional service provided to customers, who can collect goods bought online very quickly and without leaving their cars. Hübner et al. (2016c) argued that retailers in moving towards an OC system typically introduce Click\&Collect as their default delivery mode, using traditional stores as pick-up points. OC retailers can use their existing stores as pick-up points, in one of two ways (Mahar et al., 2012; Lang and Bressolles, 2013), site-to-store (i.e. the online order is supplied from the warehouse and sent to the store chosen by customer) and immediate pick-up in store (i.e. the online order is forwarded to the store chosen by customer, pickers walk down the aisles and retrieve the product/s requested). Mahar et al. (2009a) identified the optimal subset of stores for in-store pick-up and returns. In a related work, Mahar et al. (2012) developed a policy that makes use of real-time store inventory information, demand forecasts and customer location to make dynamic adjustments to the set of available stores viewed by online customers looking for pick-up points. Gallino and Moreno (2014) showed that Click\&Collect results in lower online sales, higher store sales and higher store traffic. In the same vein, Cao et al. (2016) argued that the new channel gives customers added convenience, which could help to increase customer loyalty and produce benefits for the retailer in the long run.

Looking at the shipment policy, OC retailers can make use of physical infrastructure and transport links to reduce their total costs and respond rapidly to their customers. When physical premises are located near the retailer's customers and when deliveries from the supply source to these locations are efficient, then the company will find it easier to organise local distribution routes (Lee and Whang, 2001). Metters and Walton (2007) proposed a conceptual framework along these lines, where they compared the two policies of bulk shipment and individual shipment, i.e. shipments of individual orders, or even individual items, using a courier delivery service (Murphy, 2003). OC retailers can implement a bulk shipment policy, using physical stores to support home delivery. Online orders are initially grouped by geographic area and transported to the store in that area; the store then acts as the starting point for local distribution routes. According to Metters and Walton (2007), a bulk shipment policy can be cost effective, but it implies a longer delivery lead-time, as each order waits for a full truckload of orders to the same area before being shipped.

\section{Research agenda for e-fulfilment and distribution when moving towards OC retailing}

Although a growing body of literature is available on logistics for companies moving towards OC retailing, a number of key topics are still under-represented or missing. The purpose of this section is 
to highlight the main gaps identified in literature and, consequently, propose directions for future research.

Regarding distribution network design, the literature has mainly focused on how online orders should be assigned within OC supply chains, while only few attempts have been made to propose dynamic allocation policies that use real-time information to re-evaluate e-fulfilment decisions in view of reducing costs. Several authors have recently analysed the potential benefits to online retailers of adjusting the allocation of online orders, bringing in the orders yet to be picked and the forecast of future demand (Acimovic and Graves, 2015; Jasin and Sinha, 2015). It would be interesting to extend these concepts to an $\mathrm{OC}$ environment, i.e. a unique and integrated management system across all channels, with shared data and cross-channel objectives. In addition, the evolution of the retail distribution network in terms of number and types of logistics facilities - a topic that appears to be central to many conferences and practitioners' papers (Jones Lang LaSalle, 2013; Retail Property Analyst, 2015) - is still under-represented. The increase in online sales and the development of new technologies, such as virtual mirrors/virtual fitting rooms and intelligent self-service kiosks, has led to a restructuring of existing infrastructure (central warehouse, stores), or to the introduction of new types of logistics facilities. Along these lines, in a study carried out by Jones Lang LaSalle in 2013, it was highlighted that the market for warehousing could become increasingly segmented as warehouses with different functions take on different forms (warehouses where goods are stocked and picked at item level, warehouses where parcels are sorted before being forwarded to local warehouses, regional warehouses for rapid last-mile delivery). Future research along this line would, therefore, be recommended.

Looking at inventory and capacity management, many studies are available that concentrate on inventory pooling effects, while other aspects of inventory management that come into play when moving towards OC retailing appear to be under-represented in literature. Assortment planning over multiple channels is a potential area for valuable future research. By considering an OC management approach, where data and objectives are integrated across all channels and customers can move seamlessly from one channel to another, it would certainly be interesting to investigate the effects of using different assortment planning strategies for different product types (e.g. slow and fast moving products) as well as the effects of reducing stock in store down to the point of using the store merely as a showroom (i.e. a display point with no stock). The only study currently available in literature that covers this issue specifically is the one by Bhatnagar and Syam (2014). Another interesting area of research concerns returned products. Returns management is one of the main challenges in OC retailing (Deloitte, 2015), as typically there is a high returns rate in the online channel, but, at the same time, the products returned are generally undamaged and have no quality-related defects. Re- 
introducing undamaged products to the sales channels and the impact of these goods on the retailer's inventory management policy is an interesting managerial problem to be addressed in future research. In terms of delivery planning and execution, more and more papers are now covering the aspect of home delivery design. However, the number of studies that specifically address this issue from the viewpoint of an OC retailer is relatively limited. First of all, the extant literature does not propose any holistic framework for the possible logistics role played by stores in OC retailing, both within the online order picking and packing process and as the starting point for local distribution routes, as a pick-up point for goods bought online and as a point of collection and management for returned products. Furthermore, there is still uncertainty surrounding the suitability of the different store involvement strategies, as well as with regards to the various contexts (industry, company size) in which each strategy performs best. Here, conceptual and empirical studies are recommended in order to identify the main strategies for store involvement and their areas of application, while quantitative models could help retailers to implement these strategies in practice and understand their costs and benefits. Secondly, despite the importance of the current delivery mode of in-store pick-up (Forrester Research, 2014), very little progress has been made in this area within academic literature. Future research on this matter is, therefore, recommended, with the purpose of proposing more efficient and effective management policies (e.g. for pick-up point supply), as well as quantitative models that can support retailers in evaluating the costs and benefits of the various solutions.

In general, an area of particular value could be to investigate the role and impact of emerging technologies and related availability of data when searching for synergy and integration among multiple channels in view of moving towards OC (e.g. inventory visibility, joint delivery planning). In addition, little attention has been paid so far to the interplay among the different logistics choices. While we found several papers addressing a specific logistics decision, we only found one paper (Hübner et al., 2016b) that proposed a comprehensive framework bringing together the various sides of the subject. The importance of considering a full business logistics model (i.e. joint adoption of specific choices in terms of distribution network design, inventory and capacity management, delivery planning and execution) is potentially another key research issue, since the different logistics decisions are closely related to each other (Hübner et al., 2015). Starting from the recent contributions available in literature (Hübner et al., 2016b; Ishfaq et al, 2016), we would recommend an empirical investigation to provide in-depth real-life case studies, together with investigating the models currently adopted, their application areas and the evolution of company choices over time. Moreover, quantitative studies could help in understanding how different business logistics models can create value for customers, since it is reasonable to assume that different models imply different performance in terms of logistics costs and customer service level. 


\section{Conclusions}

Retailing is at an exciting stage. In the recent past, the progressive growth of e-commerce sales and the increased deployment of new technologies have created additional opportunities and challenges for retailers. These dynamics have been making logistics-related activities - e-fulfilment and distribution specifically - more and more critical, engendering a significant number of works on this subject. In line with this premise, the aim of this study was to provide an up-to-date systematic review of the literature on the evolution of e-fulfilment and distribution when moving towards OC retailing. Even though previous reviews dealing with this topic were found in literature, they presented several limitations relating either to the timeframe being considered (lack of recent contributions) or content (lack of an exhaustive description of the logistics issues involved or focus on a particular methodology). This review was specifically developed to overcome the above-mentioned limitations. The analysis involved 58 contributions published between 2002 and 2017. The papers were analysed and categorised according to their defining characteristics, the methodology adopted and the theme tackled. The selected contributions were distributed among 34 different journals, including journals belonging to management, marketing, operations and supply chain management areas. In terms of regions addressed, the literature mainly comes from those countries where e-commerce and OC retailing are actually well developed (e.g. in 21 papers, the first author's country is the USA). Regarding the methodology, this review revealed that many of the examined contributions are based on either simulation or analytical models.

To structure the review and address RQ1, we mapped the main issues relating to e-fulfilment and distribution in retailing along three dimensions, namely distribution network design, inventory and capacity management, delivery planning and execution. We discussed the main issues and how they have been developed over time. We also highlighted the emerging issues for companies moving towards OC retailing and proposed a research agenda. Table IV summaries the main issues concerning e-fulfilment and distribution that emerge when moving towards OC retailing. While a MC system is characterised by the co-existence of multiple channels with fragmented supply chains, retailers willing to adopt an OC approach feel the need to review their business logistics model by adopting a comprehensive perspective, with a search for synergy and integration among different channels (e.g. picking integration, inventory aggregation and visibility).

XXXXXXXXXXXXXXXXXXXXXXXXXXXXXXXXXXXXXXXXXXXXXXXXXXXXXXX

Take in Table IV 
The literature review has shown that a number of important topics have not been adequately addressed or considered at all. As far as distribution network design is concerned, the dynamic assignment policy of online orders and the network evolution in terms of number and types of logistics facilities appear to be under-represented in literature. Regarding inventory management, contributions on assortment planning within different channels are currently rare. In terms of delivery planning and execution, the studies available in literature do not offer an exhaustive description of the different strategies of stores involvement. It would be interesting to understand when and how OC retailers can use stores to reduce shipping costs, improve service level and compete with online retailers. Finally, future efforts are recommended to investigate the business logistics models currently adopted by companies moving towards OC with a two-fold aim: on the one hand, to understand the evolution of company choices over time and, on the other, to identify the contexts in which different models turn out to be the most suitable.

This study offers both academic and practical implications. From an academic perspective, the paper provides a valuable guide to analyse the existing body of research on logistics when moving towards OC retailing, highlighting gaps and streams for future studies in this promising field.

From a practical viewpoint, as the paper provides an exhaustive description of the main issues related to e-fulfilment and distribution, it can be of use to retailers who are moving towards an OC approach to guide them in their effort to fine-tune their business logistics model. In other words, companies can use this study when designing their business logistics model, as it can help them to evaluate how to make coherent decisions about their e-fulfilment and distribution operations.

Although interesting findings came out from this study, limitations do exist. In particular, the main limitation lies in the potential omission of relevant contributions from the review. Although the keyword structure was trialled repeatedly during its design in order to achieve a highly effective and feasible research space, we cannot exclude the possibility that other papers dealing with this subject do exist, but under different labels. Nevertheless, precisely because of the methodology adopted, we believe that this analysis provides an adequate representation of the state-of-the art of literature relating to the logistics at play when moving towards OC retailing.

\section{References}

Acimovic, J. and Graves, S. C. (2015), "Making better fulfillment decisions on the fly in an online retail environment”, Manufacturing and Service Operations Management, Vol. 17 No. 1, pp. 3451.

Agatz, N., Fleischmann, M. and Van Nunen, J. A. (2008), "E-fulfillment and multi-channel distribution-A review", European Journal of Operational Research, Vol. 187 No. 2, pp. 339356. 
Agatz, N., Campbell, A., Fleischmann, M., and Savelsbergh, M. (2011), "Time slot management in attended home delivery", Transportation Science, Vol. 45 No. 3, pp. 435-449.

Aksen, D. and Altinkemer, K. (2008), "A location-routing problem for the conversion to the "clickand-mortar" retailing: The static case", European Journal of Operational Research, Vol. 186 No. 2, pp. 554-575.

Alptekinoğlu, A. and Tang, C. S. (2005), “A model for analyzing multi-channel distribution systems", European Journal of Operational Research, Vol. 163 No. 3, pp. 802-82.

AT Kearney (2015), "Global retail e-commerce keeps on clicking”, available at https://www.atkearney.com/consumer-products-retail/e-commerce-index/full-report//asset_publisher/87xbENNHPZ3D/content/global-retail-e-commerce-keeps-on-clicking/10192 (accessed 20 January 2016).

Beck, N. and Rygl, D. (2015), "Categorization of multiple channel retailing in Multi-, Cross-, and Omni-Channel Retailing for retailers and retailing", Journal of Retailing and Consumer Services, Vol. 27, pp. 170-178.

Bendoly, E. (2004), "Integrated inventory pooling for firms servicing both on-line and store demand", Computers and Operations Research, Vol. 31 No. 9, pp. 1465-1480.

Bendoly, E., Blocher, D., Bretthauer, K. M. and Venkataramanan, M. A. (2007), "Service and cost benefits through clicks-and-mortar integration: implications for the centralization/decentralization debate", European Journal of Operational Research, Vol. 180 No. 1, pp. 426-442.

Berman, B. and Thelen, S. (2004), "A guide to developing and managing a well-integrated multichannel retail strategy", International Journal of Retail and Distribution Management, Vol. 32 No. 3, pp.147 - 156

Bernon, M., Cullen, J. and Gorst, J. (2016), “Online retail returns management: Integration within an omni-channel distribution context”, International Journal of Physical Distribution and Logistics Management, Vol. 46 No. 6/7.

Bhatnagar, A. and Syam, S. S. (2014), “Allocating a hybrid retailer's assortment across retail stores: Bricks-and-mortar vs online”, Journal of Business Research, Vol. 67 No. 6, pp. 1293-1302.

Boyaci, T. (2005), "Competitive stocking and coordination in a multiple-channel distribution system”, IIE Transactions, Vol. 37 No. 5, pp. 407-427.

Boyer, K. K., Prud'homme, A. M. and Chung, W. (2009), "The last mile challenge: evaluating the effects of customer density and delivery window patterns", Journal of Business Logistics, Vol. 30 No. 1, pp. 185-201.

Bretthauer, K. M., Mahar, S. and Venakataramanan, M. A. (2010), "Inventory and distribution strategies for retail/e-tail organizations", Computers and Industrial Engineering, Vol. 58 No. 1, pp. 119-132. 
Brynjolfsson, E., Hu, Y. and Simester, D. (2011), “Goodbye pareto principle, hello long tail: The effect of search costs on the concentration of product sales", Management Science, Vol. 57 No. 8, pp. 1373-1386.

Burt, S., and Sparks, L. (2003), "E-commerce and the retail process: a review", Journal of Retailing and Consumer Services, Vol. 10 No. 5, pp. 275-286.

Cao, J., So, K. C. and Yin, S. (2016), "Impact of an "online-to-store" channel on demand allocation, pricing and profitability”, European Journal of Operational Research, Vol. 248 No. 1, pp. 234245.

Carter, C.R. and Rogers, D.S. (2008), "A framework of sustainable supply chain management: moving toward new theory", International Journal of Physical Distribution and Logistics Management, Vol. 38 No. 5, pp. 360-387.

Chen, J. and Bell, P. C. (2012), "Implementing market segmentation using full-refund and no-refund customer returns policies in a dual-channel supply chain structure", International Journal of Production Economics, Vol. 136 No. 1, pp. 56-66.

Chen, B. and Chen, J. (2017), "When to introduce an online channel, and offer money back guarantees and personalized pricing?", European Journal of Operational Research, Vol. 257 No. 2, pp. 614624.

Chiang, W. Y. K. and Monahan, G. E. (2005), "Managing inventories in a two-echelon dual-channel supply chain”, European Journal of Operational Research, Vol. 162 No. 2, pp. 325-341.

Colla, E. and Lapoule, P. (2012), "E-commerce: exploring the critical success factors", International Journal of Retail and Distribution Management, Vol. 40 No. 11, pp. 842-864.

Currah, A. (2002), "Behind the web store: the organisational and spatial evolution of multichannel retailing in Toronto", Environment and Planning A, Vol. 34 No. 8, pp. 1411-1441.

De Koster, R. B. M. (2002) "Distribution structures for food home shopping", International Journal of Physical Distribution and Logistics Management, Vol. 32 No. 5, pp.362 - 380.

De Koster, R. B. M. (2003), "Distribution strategies for online retailers", IEEE Transactions on Engineering Management, Vol. 50 No. 4, pp. 448-457.

Deloitte (2015), “Omni-channel retail. A Deloitte point of view”, available at https://www2.deloitte.com/content/dam/Deloitte/se/Documents/technology/Omni-channel2015.pdf (accessed 04 April 2016).

Denyer, D. and Tranfield, D. (2009), "Producing a systematic review", Chapter 39, in Buchanan, D. and Bryman, A. (Eds), The Sage Handbook of Organizational Research Methods, Sage Publications Ltd, London, pp. 671-689.

Durach, C. F., Wieland, A. and Machuca, J. A. (2015), “Antecedents and dimensions of supply chain robustness: a systematic literature review", International Journal of Physical Distribution and Logistics Management, Vol. 45 No. 1/2, pp. 118-137. 
Fairchild, A. M. (2014), "Extending the network: Defining product delivery partnering preferences for omni-channel commerce", Procedia Technology, Vol. 16, pp. 447-451.

Fernie, J. and Grant, D. B. (2008), “On-shelf availability: the case of a UK grocery retailer", The International Journal of Logistics Management, Vol. 19 No. 3, pp. 293-308.

Forrester Research (2014), "Customer desires vs retailer capabilities: minding the omni-channel commerce gap", available at https://www.sap.com/bin/sapcom/en_us/downloadasset.2014-05may-29-15.customer-desires-vs-retailer-capabilities-minding-the-omni-channel-commerce-gappdf.bypassReg.html (accessed 25 November 2015).

Gallino, S. and Moreno, A. (2014), "Integration of online and offline channels in retail: The impact of sharing reliable inventory availability information", Management Science, Vol. 60 No. 6, pp. 1434-1451.

Geng, Q. and Mallik, S. (2007), "Inventory competition and allocation in a multi-channel distribution system”, European Journal of Operational Research, Vol. 182 No. 2, pp. 704-729.

Gimenez, C. and Tachizawa, E.M. (2012), "Extending sustainability to suppliers: a systematic literature review”, Supply Chain Management: An International Journal, Vol. 17 No. 5, pp. 531543.

Gligor, D.M. and Holcomb, M.C. (2012), “Antecedents and consequences of supply chain agility: establishing the link to firm performance", Journal of Business Logistics, Vol. 33 No. 4, pp. 295 308.

Hofmann, E. and Bosshard, J. (2017), "Supply chain management and activity-based costing: Current status and directions for the future", International Journal of Physical Distribution and Logistics Management, Vol. 47No. 8, pp. 712-735.

Hohenstein, N., Feisel, E. Hartmann, E. and Giunipero, L. (2015), "Research on the phenomenon of supply chain resilience: A systematic review and paths for further investigation", International Journal of Physical Distribution and Logistics Management, Vol. 45 No. 1/2, pp. 90-117.

Hovelaque, V., Soler, L. G. and Hafsa, S. (2007), "Supply chain organization and e-commerce: a model to analyze store-picking, warehouse-picking and drop-shipping”, 4OR, Vol. 5 No. 2, pp. 143-155.

Hu, K. Y. and Chang, T. S. (2009), “An Innovative Logistics Model for Multi-Channel Retailing”, Journal of the Chinese Institute of Industrial Engineers, Vol. 26 No. 5, pp. 327-336.

Hübner, A., Holzapfel, A. and Kuhn, H. (2015), "Operations management in multi-channel retailing: an exploratory study”, Operations Management Research, Vol. 8 No. 3, pp. 84-100.

Hübner, A., Holzapfel, A. and Kuhn, H. (2016a), "Distribution systems in omni-channel retailing", Business Research, pp. 1-42. 
Hübner, A., Kuhn, H. and Wollenburg, J. (2016b), "Last mile fulfilment and distribution in omnichannel grocery retailing: A strategic planning framework", International Journal of Retail and Distribution Management, Vol. 44 No. 3, pp. 228-247.

Hübner, A., Wollenburg, J. and Holzapfel, A. (2016c), "Retail logistics in the transition from multichannel to omni-channel" International Journal of Physical Distribution and Logistics Management, Vol. 46 No. 6/7.

Ishfaq, R., Defee, C., Gibson, B. J. and Raja, U. (2016), "Realignment of the physical distribution process in omni-channel fulfilment", International Journal of Physical Distribution and Logistics Management, Vol. 46 No. 6/7, pp. $543-561$.

Jasin, S., and Sinha, A. (2015), “An LP-Based Correlated Rounding Scheme for Multi-Item Ecommerce Order Fulfillment”, Operations Research, Vol. 63 No. 6, pp. 1336-1351.

Jeanpert, S., and Paché, G. (2016), "Successful multi-channel strategy: mixing marketing and logistical issues", Journal of Business Strategy, Vol. 37 No. 2, pp. 12-19.

Jones Lang LaSalle (2013), "E-commerce boom triggers transformation in retail logistics: driving a global wave of demand for new logistics facilities", available at: http://www.jll.com/Research (accessed 1 June 2015).

Kämäräinen, V. and Punakivi, M. (2002), "Developing cost-effective operations for the e-grocery supply chain”, International Journal of Logistics, Vol. 5 No. 3, pp. 285-298.

Kull, T. J., Barratt, M., Sodero, A. C. and Rabinovich, E. (2013), "Investigating the effects of daily inventory record inaccuracy in multichannel retailing", Journal of Business Logistics, Vol. 34 No. 3, pp. 189-208.

Kumar, S., Eidem, J. and Noriega Perdomo, D. (2012), "Clash of the e-commerce titans: A new paradigm for consumer purchase process improvement", International Journal of Productivity and Performance Management, Vol. 61 No. 7, pp. 805-830.

Lagorio, A., Pinto, R. and Golini, R. (2016), "Research in urban logistics: a systematic literature review", International Journal of Physical Distribution and Logistics Management, Vol. 46 No. 10, pp. 908-931.

Lang, G. and Bressolles, G. (2013), "Economic performance and customer expectation in efulfillment systems: A multi-channel retailer perspective", Supply Chain Forum: An International Journal, Vol. 14 No. 1, pp. 16-26.

Lee, H. L. and Whang, S. (2001), "Winning the last mile of e-commerce", MIT Sloan Management Review, Vol. 42 No. 4, pp. 54-62.

Li, Y., Guo, H., Wang, L. and Fu, J. (2013), “A hybrid genetic-simulated annealing algorithm for the location-inventory-routing problem considering returns under E-supply chain environment", The Scientific World Journal, 2013. 
Li, T., Zhao, X. and Xie, J. (2015a), "Inventory management for dual sales channels with inventorylevel-dependent demand", Journal of the Operational Research Society, Vol. 66 No. 3, pp. 488499.

Li, Z., Lu, Q. and Talebian, M. (2015b), “Online versus bricks-and-mortar retailing: a comparison of price, assortment and delivery time", International Journal of Production Research, Vol. 53 No. 13 , pp. 3823-3835.

Light, R.J. and Pillemer, D.B. (1984). Summing up: The science of reviewing research. Harvard, MA: Harvard University Press.

Lightfoot, H., Baines, T. and Smart, P. (2013), "The servitization of manufacturing: a systematic literature review of interdependent trends", International Journal of Operations and Production Management, Vol. 33 Nos 11-12, pp. 1408-1434.

Liu, K. and Zhang, Z. (2007), "Capacity allocation in a competitive multi-channel supply chain", Journal of Systems Science and Systems Engineering, Vol. 16 No. 4, pp. 450-468.

Liu, K., Zhou, Y. and Zhang, Z. (2010), "Capacitated location model with online demand pooling in a multi-channel supply chain”, European Journal of Operational Research, Vol. 207 No. 1, pp. 218-231.

Mahar, S., Bretthauer, K. M. and Venkataramanan, M. A. (2009a), "An algorithm for solving the multi-period online fulfillment assignment problem", Mathematical and Computer Modelling, Vol. 50 No. 9, pp. 1294-1304.

Mahar, S., Bretthauer, K. M. and Venkataramanan, M. A. (2009b), "The value of virtual pooling in dual sales channel supply chains", European Journal of Operational Research, Vol. 192 No. 2, pp. 561-575.

Mahar, S., Salzarulo, P. A. and Wright, P. D. (2012), "Using online pickup site inclusion policies to manage demand in retail/E-tail organizations", Computers and Operations Research, Vol. 39 No. 5, pp. 991-999.

Mahar, S. and Wright, P. D. (2009), "The value of postponing online fulfillment decisions in multichannel retail/e-tail organizations", Computers and Operations Research, Vol. 36 No. 11, pp. 3061-3072.

Mahar, S., Wright, P. D., Bretthauer, K. M. and Hill, R. P. (2014), “Optimizing marketer costs and consumer benefits across "clicks" and "bricks", Journal of the Academy of Marketing Science, Vol. 42 No. 6, pp. 619-641.

Mangiaracina, R., Marchet, G., Perotti, S. and Tumino, A. (2015), “A review of the environmental implications of B2C e-commerce: a logistics perspective", International Journal of Physical Distribution and Logistics Management, Vol. 45 No. 6, pp. 565 - 591.

Mangiaracina, R. and Melacini, M. (2013), "E-commerce in the Grocery Industry: an Assessment of Distribution Strategies", Global Journal on Technology, Vol. 3. 
Marchet, G., Melacini, M. and Perotti, S. (2014), "Environmental sustainability in logistics and freight transportation: a literature review and research agenda", Journal of Manufacturing Technology Management, Vol. 25 No. 6, pp. 775-811.

Matsui, K. (2016), "Asymmetric product distribution between symmetric manufacturers using dualchannel supply chains", European Journal of Operational Research, Vol. 248 No. 2, pp. 646657.

Metters, R. and Walton, S. (2007), "Strategic supply chain choices for multi-channel Internet retailers", Service Business, Vol. 1 No. 4, pp. 317-331.

Meredith, J. (1993), "Theory building through conceptual methods", International Journal of Operations and Production Management, Vol. 13 No. 5, pp. 3-11.

Min, H., Ko, H. J. and Ko, C. S. (2006), "A genetic algorithm approach to developing the multiechelon reverse logistics network for product returns”, Omega, Vol. 34 No. 1, pp. 56-69.

Mirsch, T., Lehrer, C. and Jung, R. (2016), "Channel Integration Towards Omnichannel Management: A Literature Review”, In Proceeding of the 20th Pacific Asia Conference on Information Systems (PACIS 2016).

Mollenkopf, D. A., Frankel, R. and Russo, I. (2011), "Creating value through returns management: Exploring the marketing-operations interface", Journal of Operations Management, Vol. 29 No. 5, pp. 391-403.

Mostard, J. and Teunter, R. (2006), "The newsboy problem with resalable returns: A single period model and case study", European Journal of Operational Research, Vol. 169 No. 1, pp. 81-96.

Murphy, A. J. (2003), “(Re) solving space and time: fulfilment issues in online grocery retailing”, Environment and Planning A, Vol. 35 No. 7, pp. 1173-1200.

Murphy, A. J. (2007), "Grounding the virtual: The material effects of electronic grocery shopping", Geoforum, Vol. 38 No. 5, pp. 941-953.

Nicholls, A. and Watson, A. (2005), "Implementing e-value strategies in UK retailing", International Journal of Retail and Distribution Management, Vol. 33 No. 6, pp. 426-443.

Noble, S. M., Griffith, D. A. and Weinberger, M. G. (2005), "Consumer derived utilitarian value and channel utilization in a multi-channel retail context", Journal of Business Research, Vol. 58 No. 12, pp. 1643-1651.

Pagh, J. D. and Cooper, M. C. (1998), "Supply chain postponement and speculation strategies: how to choose the right strategy", Journal of Business Logistics, Vol. 19, pp. 13-34.

Randall, T., Netessine, S. and Rudi, N. (2006), “An empirical examination of the decision to invest in fulfillment capabilities: A study of Internet retailers", Management Science, Vol. 52 No. 4, pp. 567-580.

Retail Property Analyst (2015), "Retail logistics - the omni-channel revolution. Real estate investment opportunities in a changing world", available at http://retailpropertyanalyst.com/wp- 
content/uploads/sites/5/2015/02/rpa-logistics-report-2015-short-with-ad.pdf (accessed 4 April 2016).

Rodríguez, B. and Aydın, G. (2015), "Pricing and assortment decisions for a manufacturer selling through dual channels", European Journal of Operational Research, Vol. 242 No. 3, pp. 901909.

Saskia, S., Mareï, N. and Blanquart, C. (2016), "Innovations in e-grocery and Logistics Solutions for Cities”, Transportation Research Procedia, Vol. 12, pp. 825-835.

Schneider, F. and Klabjan, D. (2013), "Inventory control in multi-channel retail", European Journal of Operational Research, Vol. 227 No. 1, pp. 101-111.

Seuring, S. and Müller, M. (2008), "From a literature review to a conceptual framework for sustainable supply chain management", Journal of Cleaner Production, Vol. 16 No. 15, pp. 1699-1710.

Statista (2017), "B2C e-commerce sales worldwide from 2012 to 2018", available at https://www.statista.com/statistics/261245/b2c-e-commerce-sales-worldwide/ (accessed 06 September 2017).

Swaminathan, J. M. and Tayur, S. R. (2003), "Models for supply chains in e-business", Management Science, Vol. 49 No. 10, pp. 1387-1406.

Takahashi, K., Aoi, T., Hirotani, D. and Morikawa, K. (2011), "Inventory control in a two-echelon dual-channel supply chain with setup of production and delivery", International Journal of Production Economics, Vol. 133 No. 1, pp. 403-415.

Touboulic, A. and Walker, H. (2015), "Theories in sustainable supply chain management: a structured literature review", International Journal of Physical Distribution and Logistics Management, Vol. 45 No. 1/2, pp. 16-42.

Tranfield, D., Denyer, D. and Smart, P. (2003), "Towards a methodology for developing evidenceinformed management knowledge by means of systematic review", British journal of management, Vol. 14 No. 3, pp. 207-222.

Verhoef, P. C., Kannan, P. K. and Inman, J. J. (2015), "From multi-channel retailing to omni-channel retailing: introduction to the special issue on multi-channel retailing", Journal of Retailing, Vol. 91 No. 2, pp. 174-181.

Weltevreden, J. W. (2008), "B2c e-commerce logistics: the rise of collection-and-delivery points in The Netherlands", International Journal of Retail and Distribution Management, Vol. 36 No. 8 , pp. 638-660.

Widodo, E., Takahashi, K., Morikawa, K., Pujawan, I. N. and Santosa, B. (2011), "Managing sales return in dual sales channel: its product substitution and return channel analysis", International Journal of Industrial and Systems Engineering, Vol. 9 No. 2, pp. 121-149 
Wilding, R. (2013), “Multichannel or omni-channel?”, Logistics and Transport Focus, Vol.15, No.10, p. 44.

Winter, M. and Knemeyer, A. M. (2013), "Exploring the integration of sustainability and supply chain management: Current state and opportunities for future inquiry", International Journal of Physical Distribution and Logistics Management, Vol. 43 No. 1, pp. 18-38.

Wollenburg, J. (2016), "Empirical Studies in Multi-and Omni-Channel Retail Operations and Logistics-A Structured Literature Review".

Xia, Y. and Zhang, G. P. (2010), "The impact of the online channel on retailers' performances: An empirical evaluation", Decision Sciences, Vol. 41 No. 3, pp. 517-546.

Xing, Y. and Grant, D. B. (2006), "Developing a framework for measuring physical distribution service quality of multi-channel and "pure player" internet retailers", International Journal of Retail and Distribution Management, Vol. 34 No. 4/5, pp. 278-289.

Xing, Y., Grant, D. B., McKinnon, A. C., and Fernie, J. (2011), “The Interface between retailers and logistics service providers in the online market", European Journal of Marketing, Vol. 45 No. 3, pp. 334-357.

Xu, H., Chu, C. and Zhang, J. (2017), "Dynamic lot-sizing models for retailers with online channels", International Journal of Production Economics, Vol. 183, pp. 171-184.

Zhang, J., Farris, P. W., Irvin, J. W., Kushwaha, T., Steenburgh, T. J. and Weitz, B. A. (2010), "Crafting integrated multichannel retailing strategies", Journal of Interactive Marketing, Vol. 24 No. 2, pp. 168-180. 


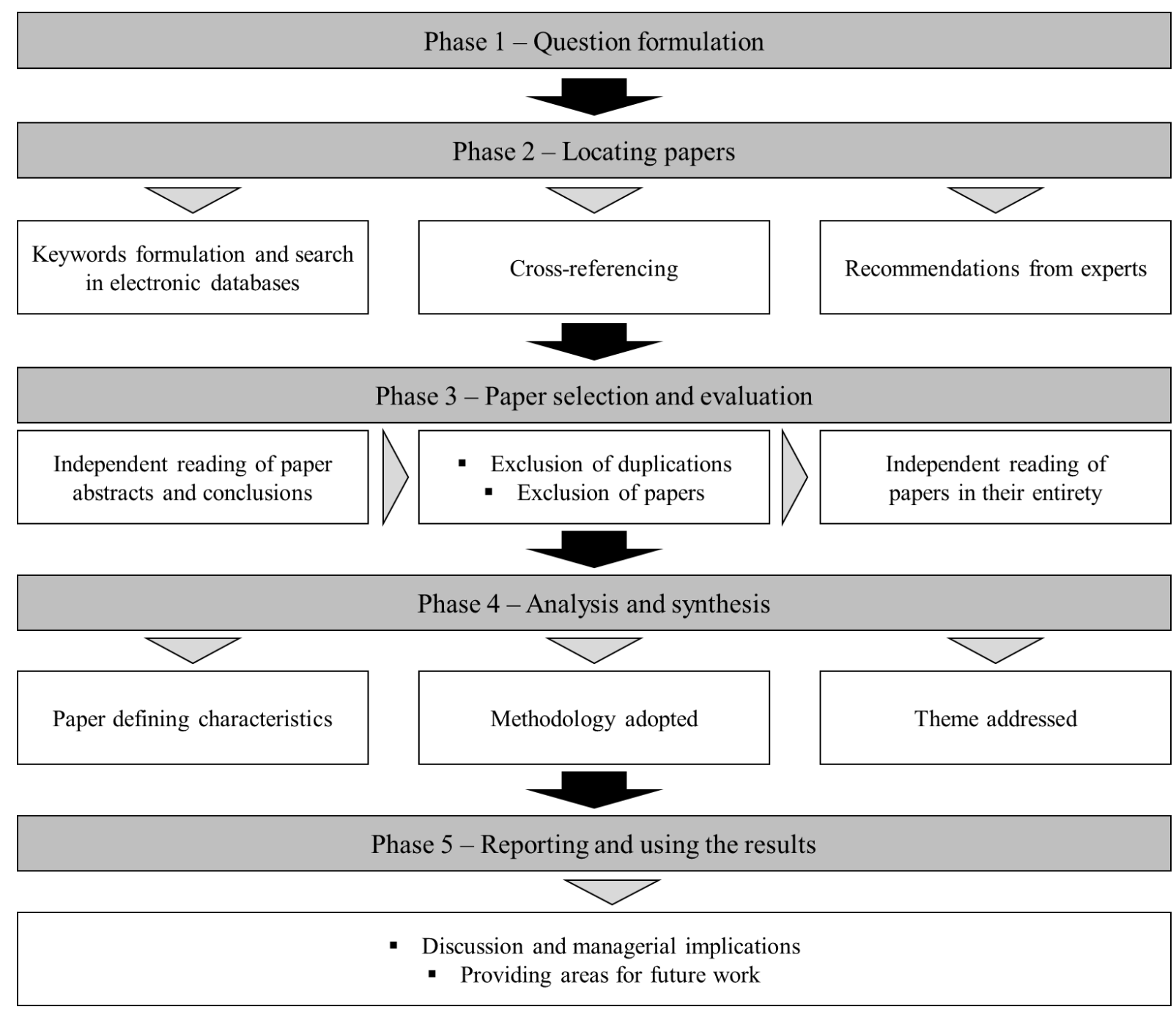

Figure 1 - SLR methodology adopted in the study, adapted from Denyer and Tranfield (2009) and Hofmann and Bosshard (2017). 


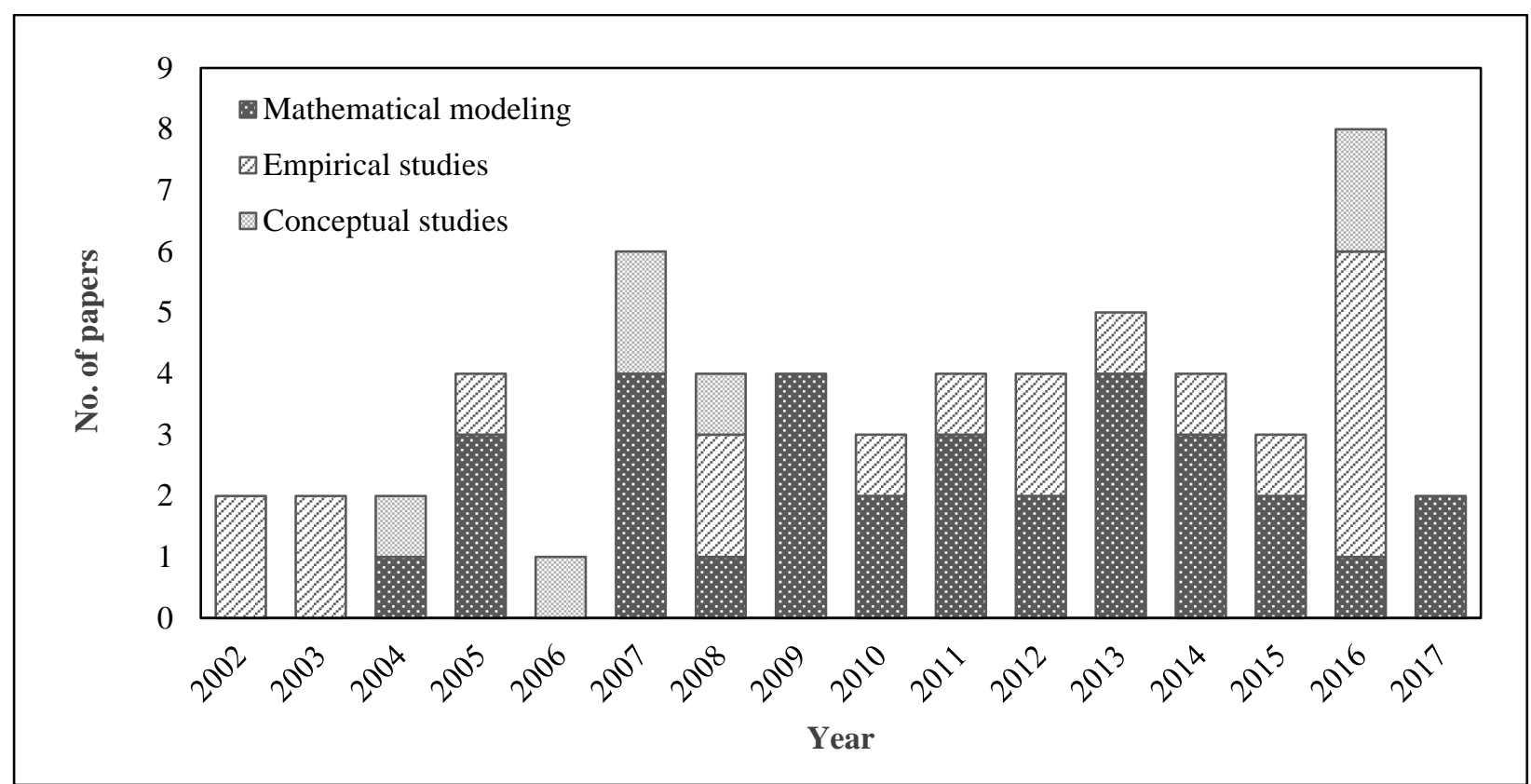

Figure 2 - Distribution of the examined papers over time with respect to the research methodology adopted. Note that in case of multiple-methods the paper was classified according to the primary methodology used in the paper. 


\begin{tabular}{|c|c|c|}
\hline & Multi-channel retailing (MC) & Omni-channel retailing (OC) \\
\hline Focus & Interactive channels only & Interactive and mass-communication channels \\
\hline Integration & Separate channels with no overlap & Integrated channels providing seamless retail experiences \\
\hline Management & $\begin{array}{l}\text { By channel, with channel objectives (i.e. } \\
\text { sales per channel, experience per channel) }\end{array}$ & $\begin{array}{l}\text { Across all channels, with cross-channel objectives (i.e. total } \\
\text { sales over channels, overall retail customer experience) }\end{array}$ \\
\hline Data & $\begin{array}{l}\text { Not integrated and not shared across } \\
\text { channels }\end{array}$ & Integrated and shared across all channels \\
\hline
\end{tabular}

Table I - MC and OC management concepts: a comprehensive overview (adapted from Verhoef et al., 2015; Mirsch et al., 2016).
( TITLE-ABS-KEY ("omni channel") OR TITLE-ABS-KEY (omnichannel) OR TITLE-ABS-KEY ("multi channel") OR TITLE-ABS-KEY ( multichannel) OR TITLE-ABS-KEY( "cross channel") OR TITLE-ABS-KEY (crosschannel) OR TITLE-ABS-KEY ("dual channel") OR TITLE-ABS-KEY ( dualchannel ) OR TITLE-ABS-KEY ("multiple channel" ) OR TITLE-ABS-KEY ( multiplechannel) OR TITLE-ABS-KEY ( clicks-and-mortar) OR TITLE-ABS-KEY (bricks-and-clicks ) OR TITLE- ABS-KEY (click-and-mortar) ) AND ( TITLE-ABS-KEY (logistics) OR TITLE-ABS-KEY( logistical) OR TITLE-ABS-KEY (operations) OR TITLE-ABS-KEY ("supply chain") OR TITLE- ABS-KEY (distribution) OR TITLE-ABS-KEY (inventory) OR TITLE-ABS-KEY (inventories ) OR TITLE-ABS-KEY (delivery) OR TITLE-ABS-KEY (deliveries) OR TITLE-ABS-KEY (fulfilment) OR TITLE-ABS-KEY ( fulfillment) OR TITLE-ABS-KEY (return*) OR TITLE-ABS-KEY( transport*) ) AND (TITLE-ABS-KEY (retail*))

Scopus

Table II - Search strings for database search: example (Scopus). 


\begin{tabular}{|c|c|c|c|c|c|c|c|c|}
\hline \multirow[b]{2}{*}{ No. } & \multirow[b]{2}{*}{ Author (year) } & \multirow[b]{2}{*}{ Country } & \multirow[b]{2}{*}{ Journal } & \multirow[b]{2}{*}{ Title } & \multirow[b]{2}{*}{ Method } & \multicolumn{3}{|c|}{ Themes addressed } \\
\hline & & & & & & (1) & (2) & (3) \\
\hline 1 & Currah (2002) & UK & Environment and Planning A & $\begin{array}{l}\text { Behind the web store: the organisational and spatial } \\
\text { evolution of multichannel retailing in Toronto }\end{array}$ & Case study & & & $\mathrm{X}$ \\
\hline 2 & De Koster (2002) & $\begin{array}{l}\text { The } \\
\text { Netherlands }\end{array}$ & $\begin{array}{l}\text { International Journal of Physical } \\
\text { Distribution and Logistics } \\
\text { Management }\end{array}$ & Distribution structures for food home shopping & Survey & $\mathrm{X}$ & & $\mathrm{X}$ \\
\hline 3 & De Koster (2003) & $\begin{array}{l}\text { The } \\
\text { Netherlands }\end{array}$ & $\begin{array}{l}\text { IEEE Transactions on Engineering } \\
\text { Management }\end{array}$ & Distribution strategy for online retailers & Survey & $\mathrm{X}$ & & $\mathrm{X}$ \\
\hline 4 & Murphy (2003) & UK & Environment and Planning A & $\begin{array}{l}(\mathrm{Re}) \text { solving space and time: fulfilment issues in online } \\
\text { grocery retailing }\end{array}$ & Case study & $\mathrm{X}$ & & $\mathrm{X}$ \\
\hline 5 & Bendoly (2004) & USA & Computers and Operations Research & $\begin{array}{l}\text { Integrated inventory pooling for firms servicing both on-line } \\
\text { and store demand }\end{array}$ & Model & & $\mathrm{X}$ & \\
\hline 6 & $\begin{array}{l}\text { Berman and } \\
\text { Thelen (2004) }\end{array}$ & USA & $\begin{array}{l}\text { International Journal of Retail and } \\
\text { Distribution Management }\end{array}$ & $\begin{array}{l}\text { A guide to developing and managing a well-integrated multi- } \\
\text { channel retail strategy }\end{array}$ & Theory & & $\mathrm{X}$ & $X$ \\
\hline 7 & $\begin{array}{l}\text { Alptekinoğlu and } \\
\text { Tang (2005) }\end{array}$ & USA & $\begin{array}{l}\text { European Journal of Operational } \\
\text { Research }\end{array}$ & A model for analyzing multi-channel distribution systems & Model & $\mathrm{X}$ & & \\
\hline 8 & Boyaci (2005) & Canada & $\begin{array}{l}\text { IIE Transactions (Institute of } \\
\text { Industrial Engineers) }\end{array}$ & $\begin{array}{l}\text { Competitive stocking and coordination in a multiple-channel } \\
\text { distribution system }\end{array}$ & Model & & $\mathrm{X}$ & \\
\hline 9 & $\begin{array}{l}\text { Chiang and } \\
\text { Monahan (2005) }\end{array}$ & USA & $\begin{array}{l}\text { European Journal of Operational } \\
\text { Research }\end{array}$ & $\begin{array}{l}\text { Managing inventories in a two-echelon dual-channel supply } \\
\text { chain }\end{array}$ & Model & & $\mathrm{X}$ & \\
\hline 10 & $\begin{array}{l}\text { Nicholls and } \\
\text { Watson (2005) }\end{array}$ & UK & $\begin{array}{l}\text { International Journal of Retail and } \\
\text { Distribution Management }\end{array}$ & Implementing e-value strategies in UK retailing & Survey & $\mathrm{X}$ & $\mathrm{X}$ & $\mathrm{X}$ \\
\hline 11 & $\begin{array}{l}\text { Xing and Grant } \\
(2006)\end{array}$ & UK & $\begin{array}{l}\text { International Journal of Retail and } \\
\text { Distribution Management }\end{array}$ & $\begin{array}{l}\text { Developing a framework for measuring physical distribution } \\
\text { service quality of multi-channel and "pure player" internet } \\
\text { retailers }\end{array}$ & Theory & $\mathrm{X}$ & & \\
\hline 12 & $\begin{array}{l}\text { Bendoly et al. } \\
\text { (2007) }\end{array}$ & USA & $\begin{array}{l}\text { European Journal of Operational } \\
\text { Research }\end{array}$ & $\begin{array}{l}\text { Service and cost benefits through clicks-and-mortar } \\
\text { integration: implications for the } \\
\text { centralization/decentralization debate }\end{array}$ & Model & & $\mathrm{X}$ & \\
\hline
\end{tabular}




\begin{tabular}{|c|c|c|c|c|c|c|c|c|}
\hline 13 & $\begin{array}{l}\text { Geng and Mallik } \\
\text { (2007) }\end{array}$ & USA & $\begin{array}{l}\text { European Journal of Operational } \\
\text { Research }\end{array}$ & $\begin{array}{l}\text { Inventory competition and allocation in a multi-channel } \\
\text { distribution system }\end{array}$ & Model & & $\mathrm{X}$ & \\
\hline 14 & $\begin{array}{l}\text { Hovelaque et al. } \\
(2007)\end{array}$ & France & 4OR & $\begin{array}{l}\text { Supply chain organization and e-commerce: a model to } \\
\text { analyze store-picking, warehouse-picking and drop-shipping }\end{array}$ & Model & $\mathrm{X}$ & & \\
\hline 15 & $\begin{array}{l}\text { Liu and Zhang } \\
\text { (2007) }\end{array}$ & China & $\begin{array}{l}\text { Journal of Systems Science and } \\
\text { Systems Engineering }\end{array}$ & $\begin{array}{l}\text { Capacity allocation in a competitive multi-channel supply } \\
\text { chain }\end{array}$ & Model & & $\mathrm{X}$ & \\
\hline 16 & $\begin{array}{l}\text { Metters and } \\
\text { Walton (2007) }\end{array}$ & USA & Service Business & $\begin{array}{l}\text { Strategic supply chain choices for multi-channel Internet } \\
\text { retailers }\end{array}$ & Theory & & $\mathrm{X}$ & $\mathrm{X}$ \\
\hline 17 & Murphy (2007) & $\begin{array}{l}\text { New } \\
\text { Zealand }\end{array}$ & Geoforum & $\begin{array}{l}\text { Grounding the virtual: the material effects of electronic } \\
\text { grocery shopping }\end{array}$ & Theory & $\mathrm{X}$ & & $\mathrm{X}$ \\
\hline 18 & $\begin{array}{l}\text { Agatz et al. } \\
(2008)\end{array}$ & $\begin{array}{l}\text { The } \\
\text { Netherlands }\end{array}$ & $\begin{array}{l}\text { European Journal of Operational } \\
\text { Research }\end{array}$ & E-fulfillment and multi-channel distribution - a review & Review & $\mathrm{X}$ & $\mathrm{X}$ & $\mathrm{X}$ \\
\hline 19 & $\begin{array}{l}\text { Aksen and } \\
\text { Altinkemer } \\
(2008)\end{array}$ & Turkey & $\begin{array}{l}\text { European Journal of Operational } \\
\text { Research }\end{array}$ & $\begin{array}{l}\text { A location-routing problem for the conversion to the click- } \\
\text { and-mortar retailing: The static case }\end{array}$ & Model & & & $\mathrm{X}$ \\
\hline 20 & $\begin{array}{l}\text { Fernie and Grant } \\
\text { (2008) }\end{array}$ & UK & $\begin{array}{l}\text { The International Journal of Logistics } \\
\text { Management }\end{array}$ & On-shelf availability: the case of a UK grocery retailer & Case study & & $\mathrm{X}$ & \\
\hline 21 & $\begin{array}{l}\text { Weltevreden } \\
(2008)\end{array}$ & $\begin{array}{l}\text { The } \\
\text { Netherlands }\end{array}$ & $\begin{array}{l}\text { International Journal of Retail and } \\
\text { Distribution Management }\end{array}$ & $\begin{array}{l}\text { B2c e-commerce logistics: the rise of collection-and-delivery } \\
\text { points in The Netherlands }\end{array}$ & Survey & & & $\mathrm{X}$ \\
\hline 22 & $\begin{array}{l}\text { Hu and Chang } \\
\text { (2009) }\end{array}$ & Taiwan & $\begin{array}{l}\text { Journal of the Chinese Institute of } \\
\text { Industrial Engineers }\end{array}$ & An innovative logistics model for multi-channel retailing & Model & $\mathrm{X}$ & & \\
\hline 23 & $\begin{array}{l}\text { Mahar et al. } \\
(2009 a)\end{array}$ & USA & $\begin{array}{l}\text { Mathematical and Computer } \\
\text { Modelling }\end{array}$ & $\begin{array}{l}\text { An algorithm for solving the multi-period online fulfillment } \\
\text { assignment problem }\end{array}$ & Model & & & $\mathrm{X}$ \\
\hline 24 & $\begin{array}{l}\text { Mahar et al. } \\
(2009 b)\end{array}$ & USA & $\begin{array}{l}\text { European Journal of Operational } \\
\text { Research }\end{array}$ & $\begin{array}{l}\text { The value of virtual pooling in dual sales channel supply } \\
\text { chains }\end{array}$ & Model & $\mathrm{X}$ & & \\
\hline 25 & $\begin{array}{l}\text { Mahar and } \\
\text { Wright (2009) }\end{array}$ & USA & Computers and Operations Research & $\begin{array}{l}\text { The value of postponing online fulfillment decisions in } \\
\text { multi-channel retail/e-tail organizations }\end{array}$ & Model & $\mathrm{X}$ & & \\
\hline 26 & $\begin{array}{l}\text { Bretthauer et al. } \\
(2010)\end{array}$ & USA & Computers and Industrial Engineering & $\begin{array}{l}\text { Inventory and distribution strategies for retail/e-tail } \\
\text { organizations }\end{array}$ & Model & $\mathrm{X}$ & & \\
\hline
\end{tabular}




\begin{tabular}{|c|c|c|c|c|c|c|c|c|}
\hline 27 & Liu et al. (2010) & China & $\begin{array}{l}\text { European Journal of Operational } \\
\text { Research }\end{array}$ & $\begin{array}{l}\text { Capacitated location model with online demand pooling in a } \\
\text { multi-channel supply chain }\end{array}$ & Model & & $\mathrm{X}$ & \\
\hline 28 & $\begin{array}{l}\text { Xia and Zhang } \\
\text { (2010) }\end{array}$ & USA & Decision Sciences & $\begin{array}{l}\text { The impact of the online channel on retailers' performances: } \\
\text { an empirical evaluation }\end{array}$ & Survey & $\mathrm{X}$ & & \\
\hline 29 & $\begin{array}{l}\text { Brynjolfsson et } \\
\text { al. (2011) }\end{array}$ & USA & Management Science & $\begin{array}{l}\text { Goodbye Pareto principle, hello long tail: the effect of search } \\
\text { costs on the concentration of product sales }\end{array}$ & Model & & $\mathrm{X}$ & \\
\hline 30 & $\begin{array}{l}\text { Takahashi et al. } \\
\text { (2011) }\end{array}$ & Japan & $\begin{array}{l}\text { International Journal of Production } \\
\text { Economics }\end{array}$ & $\begin{array}{l}\text { Inventory control in a two-echelon dual-channel supply } \\
\text { chain with setup of production and delivery }\end{array}$ & Model & & $\mathrm{X}$ & \\
\hline 31 & $\begin{array}{l}\text { Widodo et al. } \\
\text { (2011) }\end{array}$ & Japan & $\begin{array}{l}\text { International Journal of Industrial and } \\
\text { Systems Engineering }\end{array}$ & $\begin{array}{l}\text { Managing sales return in dual sales channel: its product } \\
\text { substitution and return channel analysis }\end{array}$ & Model & $\mathrm{X}$ & & \\
\hline 32 & Xing et al. (2011) & UK & European Journal of Marketing & $\begin{array}{l}\text { The interface between retailers and logistics service } \\
\text { providers in the online market }\end{array}$ & Case study & & & $\mathrm{X}$ \\
\hline 33 & $\begin{array}{l}\text { Chen and Bell } \\
\text { (2012) }\end{array}$ & Canada & $\begin{array}{l}\text { International Journal of Production } \\
\text { Economics }\end{array}$ & $\begin{array}{l}\text { Implementing market segmentation using full-refund and no- } \\
\text { refund customer returns policies in a dual-channel supply } \\
\text { chain structure }\end{array}$ & Model & & & $\mathrm{X}$ \\
\hline 34 & $\begin{array}{l}\text { Colla and } \\
\text { Lapoule (2012) }\end{array}$ & France & $\begin{array}{l}\text { International Journal of Retail and } \\
\text { Distribution Management }\end{array}$ & E-commerce: exploring the critical success factors & Case study & & & $\mathrm{X}$ \\
\hline 35 & $\begin{array}{l}\text { Kumar et al. } \\
\text { (2012) }\end{array}$ & USA & $\begin{array}{l}\text { International Journal of Productivity } \\
\text { and Performance Management }\end{array}$ & $\begin{array}{l}\text { Clash of the e-commerce titans: a new paradigm for } \\
\text { consumer purchase process improvement }\end{array}$ & Case study & $\mathrm{X}$ & & \\
\hline 36 & $\begin{array}{l}\text { Mahar et al. } \\
\text { (2012) }\end{array}$ & USA & Computers and Operations Research & $\begin{array}{l}\text { Using online pickup site inclusion policies to manage } \\
\text { demand in retail/E-tail organizations }\end{array}$ & Model & & & $\mathrm{X}$ \\
\hline 37 & Kull et al. (2013) & USA & Journal of Business Logistics & $\begin{array}{l}\text { Investigating the effects of daily inventory record inaccuracy } \\
\text { in multichannel retailing }\end{array}$ & Model & & $\mathrm{X}$ & \\
\hline 38 & $\begin{array}{l}\text { Lang and } \\
\text { Bressolles (2013) }\end{array}$ & France & $\begin{array}{l}\text { Supply Chain Forum: An } \\
\text { International Journal }\end{array}$ & $\begin{array}{l}\text { Economic performance and customer expectation in e- } \\
\text { fulfillment systems: a multi-channel retailer perspective }\end{array}$ & Case study & $\mathrm{X}$ & & $\mathrm{X}$ \\
\hline 39 & Li et al. (2013) & China & The Scientific World Journal & $\begin{array}{l}\text { A hybrid genetic-simulated annealing algorithm for the } \\
\text { location-inventory-routing problem considering returns } \\
\text { under e-supply chain environment }\end{array}$ & Model & & $\mathrm{X}$ & \\
\hline 40 & $\begin{array}{l}\text { Mangiaracina and } \\
\text { Melacini (2013) }\end{array}$ & Italy & Global Journal on Technology & $\begin{array}{l}\text { E-commerce in the grocery industry: an assessment of } \\
\text { distribution strategies }\end{array}$ & Model & $\mathrm{X}$ & & \\
\hline
\end{tabular}




\begin{tabular}{|c|c|c|c|c|c|c|c|c|}
\hline 41 & $\begin{array}{l}\text { Schneider and } \\
\text { Klabjan (2013) }\end{array}$ & Germany & $\begin{array}{l}\text { European Journal of Operational } \\
\text { Research }\end{array}$ & Inventory control in multi-channel retail & Model & & $\mathrm{X}$ & \\
\hline 42 & $\begin{array}{l}\text { Bhatnagar and } \\
\text { Syam (2014) }\end{array}$ & USA & Journal of Business Research & $\begin{array}{l}\text { Allocating a hybrid retailer's assortment across retail stores: } \\
\text { bricks-and-mortar vs online }\end{array}$ & Model & & $\mathrm{X}$ & \\
\hline 43 & Fairchild (2014) & Belgium & Procedia Technology & $\begin{array}{l}\text { Extending the network: defining product delivery partnering } \\
\text { preferences for omni-channel commerce }\end{array}$ & Survey & & & $\mathrm{X}$ \\
\hline 44 & $\begin{array}{l}\text { Gallino and } \\
\text { Moreno (2014) }\end{array}$ & USA & Management Science & $\begin{array}{l}\text { Integration of online and offline channels in retail: the } \\
\text { impact of sharing reliable inventory availability information }\end{array}$ & Model & & $\mathrm{X}$ & \\
\hline 45 & $\begin{array}{l}\text { Mahar et al. } \\
\text { (2014) }\end{array}$ & USA & $\begin{array}{l}\text { Journal of the Academy of Marketing } \\
\text { Science }\end{array}$ & $\begin{array}{l}\text { Optimizing marketer costs and consumer benefits across } \\
\text { "clicks" and "bricks" }\end{array}$ & Model & & & $\mathrm{X}$ \\
\hline 46 & $\begin{array}{l}\text { Hübner et al. } \\
\text { (2015) }\end{array}$ & Germany & Operations Management Research & $\begin{array}{l}\text { Operations management in multi-channel retailing: an } \\
\text { exploratory study }\end{array}$ & Survey & $\mathrm{X}$ & $\mathrm{X}$ & \\
\hline 47 & Li et al. (2015a) & China & $\begin{array}{l}\text { Journal of the Operational Research } \\
\text { Society }\end{array}$ & $\begin{array}{l}\text { Inventory management for dual sales channels with } \\
\text { inventory-level-dependent demand }\end{array}$ & Model & & $\mathrm{X}$ & \\
\hline 48 & Li et al. (2015b) & Australia & $\begin{array}{l}\text { International Journal of Production } \\
\text { Research }\end{array}$ & $\begin{array}{l}\text { Online versus bricks-and-mortar retailing: a comparison of } \\
\text { price, assortment and delivery time }\end{array}$ & Model & & $\mathrm{X}$ & \\
\hline 49 & $\begin{array}{l}\text { Bernon et al. } \\
(2016)\end{array}$ & UK & $\begin{array}{l}\text { International Journal of Physical } \\
\text { Distribution and Logistics } \\
\text { Management }\end{array}$ & $\begin{array}{l}\text { Online retail returns management: integration within an } \\
\text { omni-channel distribution context }\end{array}$ & Theory & $\mathrm{X}$ & & \\
\hline 50 & Cao et al. (2016) & Canada & $\begin{array}{l}\text { European Journal of Operational } \\
\text { Research }\end{array}$ & $\begin{array}{l}\text { Impact of an "online-to-store" channel on demand allocation, } \\
\text { pricing and profitability }\end{array}$ & Model & & $\mathrm{X}$ & \\
\hline 51 & $\begin{array}{l}\text { Hübner et al. } \\
\text { (2016a) }\end{array}$ & Germany & Business Research & Distribution systems in omni-channel retailing & Case study & $\mathrm{X}$ & $\mathrm{X}$ & $\mathrm{X}$ \\
\hline 52 & $\begin{array}{l}\text { Hübner et al. } \\
\text { (2016b) }\end{array}$ & Germany & $\begin{array}{l}\text { International Journal of Retail and } \\
\text { Distribution Management }\end{array}$ & $\begin{array}{l}\text { Last mile fulfilment and distribution in omni-channel } \\
\text { grocery retailing: a strategic planning framework }\end{array}$ & Case study & $\mathrm{X}$ & $\mathrm{X}$ & $\mathrm{X}$ \\
\hline 53 & $\begin{array}{l}\text { Hübner et al. } \\
\text { (2016c) }\end{array}$ & Germany & $\begin{array}{l}\text { International Journal of Physical } \\
\text { Distribution and Logistics } \\
\text { Management }\end{array}$ & $\begin{array}{l}\text { Retail logistics in the transition from multi-channel to omni- } \\
\text { channel }\end{array}$ & Survey & $\mathrm{X}$ & $\mathrm{X}$ & $\mathrm{X}$ \\
\hline
\end{tabular}




\begin{tabular}{|c|c|c|c|c|c|c|c|c|}
\hline 54 & $\begin{array}{l}\text { Ishfaq et al. } \\
\text { (2016) }\end{array}$ & USA & $\begin{array}{l}\text { International Journal of Physical } \\
\text { Distribution and Logistics } \\
\text { Management }\end{array}$ & $\begin{array}{l}\text { Realignment of the physical distribution process in omni- } \\
\text { channel fulfilment }\end{array}$ & Case study & $\mathrm{X}$ & & $\mathrm{X}$ \\
\hline 55 & $\begin{array}{l}\text { Jeanpert and } \\
\text { Paché (2016) }\end{array}$ & France & Journal of Business Strategy & $\begin{array}{l}\text { Successful multi-channel strategy: mixing marketing and } \\
\text { logistical issues }\end{array}$ & Case study & & & $\mathrm{X}$ \\
\hline 56 & $\begin{array}{l}\text { Saskia et al. } \\
(2016)\end{array}$ & Germany & Transportation Research Procedia & Innovations in e-grocery and Logistics Solutions for Cities & Theory & $\mathrm{X}$ & & $\mathrm{X}$ \\
\hline 57 & $\begin{array}{l}\text { Chen and Chen } \\
\text { (2017) }\end{array}$ & USA & $\begin{array}{l}\text { European Journal of Operational } \\
\text { Research }\end{array}$ & $\begin{array}{l}\text { When to introduce an online channel, and offer money back } \\
\text { guarantees and personalized pricing? }\end{array}$ & Model & $\mathrm{X}$ & & \\
\hline 58 & Xu et al. (2017) & China & $\begin{array}{l}\text { International Journal of Production } \\
\text { Economics }\end{array}$ & Dynamic lot-sizing models for retailers with online channels & Model & & $\mathrm{X}$ & \\
\hline
\end{tabular}

Table III - Summary of the reviewed papers. 


\begin{tabular}{|c|c|c|c|}
\hline & & Multi-channel retailing (MC) & Omni-channel retailing (OC) \\
\hline \multirow{2}{*}{$\begin{array}{l}\text { Distribution } \\
\text { network design }\end{array}$} & $\begin{array}{l}\text { Distribution } \\
\text { system }\end{array}$ & Inventory location, picking location & Inventory aggregation, picking integration \\
\hline & $\begin{array}{l}\text { Logistics } \\
\text { facilities }\end{array}$ & $\begin{array}{l}\text { Design of e-fulfilment centre } \\
\text { (automation degree, layout), design of } \\
\text { return centre }\end{array}$ & $\begin{array}{l}\text { Traditional warehouse restructuring, role of } \\
\text { store, store restructuring }\end{array}$ \\
\hline \multirow{2}{*}{$\begin{array}{l}\text { Inventory and } \\
\text { capacity } \\
\text { management }\end{array}$} & $\begin{array}{l}\text { Assortment } \\
\text { planning }\end{array}$ & Assortment overlapping & Assortment integration \\
\hline & $\begin{array}{l}\text { Replenishment } \\
\text { policy }\end{array}$ & $\begin{array}{l}\text { Definition of stock level for online } \\
\text { channel, integration of returns }\end{array}$ & $\begin{array}{l}\text { Aggregation of stock levels, integration of } \\
\text { control policies, inventory visibility, channels } \\
\text { priorities }\end{array}$ \\
\hline \multirow{2}{*}{$\begin{array}{l}\text { Delivery planning } \\
\text { and execution }\end{array}$} & $\begin{array}{l}\text { Delivery } \\
\text { service }\end{array}$ & $\begin{array}{l}\text { Types of home delivery, velocity, time } \\
\text { slot, price differentiation }\end{array}$ & $\begin{array}{l}\text { Alternative delivery modes (Click\&Collect, } \\
\text { Click\&Drive) }\end{array}$ \\
\hline & $\begin{array}{l}\text { Shipment } \\
\text { policy }\end{array}$ & Routing for home delivery & Joint delivery \\
\hline
\end{tabular}

Table IV - Main issues related to e-fulfilment and distribution in MC and OC retailing, mapped on three dimensions: distribution network design, inventory and capacity management, delivery planning and execution. 